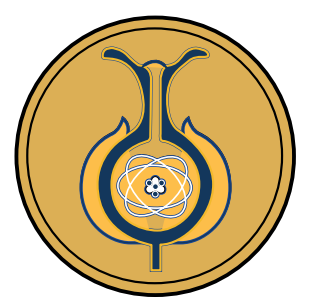

\title{
Effect of two surfactants on in vitro permeation of butorphanol through horse nasal mucosa
}

\author{
Efecto de dos surfactantes en la permeabilidad in vitro de butorfanol a través \\ de mucosa nasal equina
}

Efeito de dois surfactantes na permeação in vitro de butorfanol através da mucosa nasal equina

María Inés Velloso $^{1}$ • Héctor Alfredo Andreetta ${ }^{2}$ María Fabiana Landoni ${ }^{1}$

Received: Sep/1/2020 • Accepted: Nov/24/2020 • Published: Jul/31/2021

\section{Abstract}

The aim of the present study was to evaluate the effect of two surfactants on in vitro permeation of butorphanol through equine nasal mucosa. Franz diffusion cells and equine nasal mucosa were used. Three formulations were developed based on citric acid, sodium citrate, sodium chloride, and butorphanol tartrate and administered at a $24.4 \mathrm{~g} \mathrm{~cm}^{-3}$ dose. Control formulation lacked any penetration enhancer. Formulation 1 (F1) had a cationic surfactant (cetrimonium bromide) and formulation 2 (F2) had a non-ionic surfactant (Tween 80 ). Statistically comparing flux values at the steady state $\left(J_{s s}\right)$, apparent permeability coefficient $\left(K_{\mathrm{p}}\right)$, and lag-time from control, F1 and F2 for the respiratory region does not show statistically significant differences $(\alpha=0.05)$. However, statistically significant differences were found on the $J_{s s}$ and $K_{p}$, values from control, F1, and F2 in olfactory mucosa. A statistical analysis on the latter showed significant differences between the $\mathrm{J}_{\mathrm{sS}}$ values of $\mathrm{F} 1$ and $\mathrm{F} 2$ and between control and $\mathrm{F} 2$. Based on this, Tween 80 proved to be a promising excipient in developing intranasal butorphanol formulations in equines since it increases its passage through the nasal mucosa. These results are very promising to continue with the development of intranasal butorphanol formulation in equines.

Keywords: butorphanol; development of intranasal formulation; equines; intranasal

\section{Resumen}

El objetivo del trabajo fue estudiar el efecto de dos surfactantes en la permeabilidad in vitro de butorfanol, a través de la mucosa nasal equina. Para ello se utilizaron celdas de difusión de Franz, mucosa nasal equina y fueron desarrolladas tres formulaciones basadas en ácido cítrico, citrato de sodio, cloruro de sodio y tartrato de butorfanol a la dosis de $24.4 \mathrm{~g} \mathrm{~cm}^{-3}$. La formulación control carecía de mejoradores de permeabilidad; la primera formulación (F1) contenía un surfactante catiónico (cetrimida) y la formulación 2 (F2) un surfactante no iónico (Tween 80). Al comparar estadísticamente los valores del flujo máximo en estado

María Inés Velloso, $\square$ vellosomariaines@gmail.com, (D https://orcid.org/0000-0001-6284-4733

Héctor Alfredo Andreetta, $\square$ alfredo.and@hotmail.com, (D https://orcid.org/0000-0003-3519-8320

María Fabiana Landoni, \ landoni@fcv.unlp.edu.ar, (1) https://orcid.org/0000-0001-7549-0866

1 Cátedra de Farmacología General y Clínica. Facultad de Ciencias Veterinarias. Universidad Nacional de La Plata, La Plata, Argentina.

2 Facultad de Ciencias Exactas, Universidad Nacional de La Plata, La Plata, Argentina 
estacionario $\left(\mathrm{J}_{\mathrm{ss}}\right)$, coeficiente de permeabilidad aparente $\left(\mathrm{K}_{\mathrm{p}}\right)$ y el tiempo lag provenientes de las mucosas nasales respiratorias de las formulaciones control, F1 y F2 no se encontraron diferencias estadísticamente significativas $(\alpha=0.05)$. Sin embargo, cuando se compararon los valores de $\mathrm{J}_{s \mathrm{~s}}$ y $\mathrm{K}_{\mathrm{p}}$ provenientes de la mucosa nasal olfatoria de las formulaciones control, F1 y F2 sí se observaron. Tras realizar un análisis estadístico sobre estos últimos se descubrieron diferencias significativas entre los valores de J de F1 y F2 y entre control y F2. Basándonos en esto, se propone que el Tween 80 podría ser un excipiente promisorio en el desarrollo de formulaciones intranasales con aplicación equina, porque incrementa el pasaje del fármaco a través de la mucosa nasal equina. Estos resultados son prometedores para continuar en el desarrollo de formulaciones intranasales de butorfanol para uso en equinos.

Palabras clave: Butorfanol; desarrollo de formulación intranasal; equinos; intranasal.

\section{Resumo}

Este trabalho teve como objetivo estudar o efeito de dois surfactantes na permeabilidade in vitro de butorfanol através da mucosa nasal equina. Para isso, foram utilizadas células de difusão de Franz, mucosa nasal equina, e desenvolvidas três formulações com base em ácido cítrico, citrato de sódio, cloreto de sódio e tartarato de butorfanol na dose de $24,4 \mathrm{~g} \mathrm{~cm}^{-3}$. A formulação controle carecia de melhoradores de permeação; a primeira formulação (F1) continha um surfactante catiônico (cetrimida) e a formulação 2 (F2) um surfactante não iônico (Tween 80). Ao comparar estatisticamente os valores do fluxo máximo em estado estacionário $\left(\mathrm{J}_{\mathrm{ss}}\right)$, coeficiente de permeabilidade aparente $\left(\mathrm{K}_{\mathrm{p}}\right)$ e 0 tempo lag $\left(\mathrm{t}_{\mathrm{lag}}\right)$ provenientes das mucosas nasais respiratórias das formulações controle, F1 e F2, não foram encontradas diferenças estatisticamente significativas $(\alpha=0.05)$. Entretanto, ao comparar os valores de $\mathrm{J}_{s s}$ e $\mathrm{K}_{\mathrm{p}}$ provenientes da mucosa nasal olfatória das formulações controle, F1 e F2, sim. Depois de realizar uma análise estatística sobre esses últimos, foram descobertas diferenças significativas entre os valores de $\mathrm{J}_{\text {ss }}$ de $\mathrm{F} 1$ e F2, e entre 0 controle e F2. Com base nisso, propõe-se que o Tween 80 poderia ser um excipiente promissor no desenvolvimento de formulações intranasais com aplicação equina, já que amplia a passagem do fármaco através da mucosa nasal equina. Estes resultados são prometedores para avançar no desenvolvimento de formulações intranasais de butorfanol para uso em equinos.

Palavras-chave: Butorfanol; desenvolvimento de formulação intranasal; equinos; intranasal.

\section{Introduction}

Butorphanol, a synthetic agonist-antagonist opioid, has become widely used in equine medicine for the management of pain (Matthews \& Carroll, 2007). It is 3 to 7 times more potent than morphine, being commonly administered by intravenous route (Dale, et al., 2002; Ferreira, et al., 2019).

In veterinary medicine, intranasal administration of opioids would be an alternative route to intravenous, subcutaneous, oral or rectal administration. However, this administration route is not commonly used in horses except for local treatments. Intranasal administration has some suitable features becoming a potential choice for drugs whose site of action is inside the central nervous system. It is a painless and non-invasive, avoiding first-pass metabolism. It seems also to be a favourable way to circumvent the blood brain barrier allowing the direct drug delivery to central nervous system (Dale, et al., 2002; Ferreira, et al., 2019; Thorat, 2016). 
Moreover, it was demonstrated that intranasal administration is well tolerated in equines (Ferreira et al., 2015).

Nowadays, the development of intranasal formulations is a challenge. Nasal drug products contain therapeutically active ingredients dissolved in solutions or mixtures of excipients. There are various types of excipients used in nasal formulations, particularly surfactants because their incorporation into an intranasal formulation can modify the permeability of nasal membranes and then, facilitate the nasal absorption of drug (Thorat, 2016).

The aim of the present study was to compare in vitro permeation of butorphanol from two formulations with two different surfactants, cetrimonium bromide (a cationic surfactant) and polysorbate 80 , (Tween 80 , a non-ionic surfactant), through horse nasal mucosa.

\section{Methodology}

\section{Materials}

All constituents used were of analytical quality. All formulations were made in distilled water. Composition of the studied formulations is listed in table 1. Once prepared, formulations were kept in fridge until experiment, which was not more than 48 hours.

\section{Methods}

\section{In vitro permeation studies}

Nasal mucosa was harvested from three healthy equines obtained from Anatomic Pathology Service, Facultad de Ciencias Veterinarias, Universidad Nacional de La Plata. Within the first hour of animal death, nasal mucosa was carefully removed and immersed in cold sterile saline solution for transportation to the laboratory. In the laboratory, mucosa was washed with fresh cold saline solution to detach remains of blood and cut in $4 \mathrm{~cm}^{2}$ squares. Pieces of olfactory and respiratory areas were mounted in Franztype diffusion cells (Franz, 1978) with the mucosa side uppermost. Diffusion area was $1.23 \mathrm{~cm}^{2}$, receptor compartment volume of saline $7.0 \mathrm{ml}$ and volume of formulation into donor compartment $1.0 \mathrm{ml}$ (corresponding to a butorphanol dose of $24.4 \mathrm{mg} / \mathrm{cm}^{2}$ ).

During all the experiment, cells were thermostatted at $37{ }^{\circ} \mathrm{C}$, stirred constantly with Teflon-coated magnetic bar and without light directly (Figure 1). Samples of 800 $\mu \mathrm{l}$ were collected hourly, over a 6 hour period, from the receptor compartment adding an equivalent amount of fresh saline solution to maintain a constant volume. Each set of experiments was performed six-fold. The samples were frozen at $-20^{\circ} \mathrm{C}$ for no longer

Table 1. Composition ( $\%, \mathrm{w} / \mathrm{v})$ of control, F1 and F2 for intranasal administration. Note: derived from research.

\begin{tabular}{lccc}
\hline & & Quantity (\%, W/V) & \\
\multicolumn{1}{c}{ Ingredients (g) } & Control & F 1 & F 2 \\
\hline Butorphanol tartrate & 3 & 3 & 3 \\
Citric acid & 0.330 & 0.330 & 0.330 \\
Trisodium citrate & 0.640 & 0.640 & 0.730 \\
Sodium chloride & 0.640 & 0.640 & 0.640 \\
Polyoxyethylene (20) sorbitan monoleate (Tween 80) & - & - & 0.030 \\
Cetrimonium bromide (CTAB) & - & 0.030 & - \\
\hline
\end{tabular}


than four weeks. After the assay the samples of mucosa were analysed to confirm their viability in Anatomic Pathology Service, Facultad de Ciencias Veterinarias, Universidad Nacional de La Plata. All animal experiments have been aproved by the Comisión Institucional para el Cuidado y Uso de Animales de Laboratorio (CICUAL), Facultad de Ciencias Veterinarias, Universidad Nacional de La Plata.

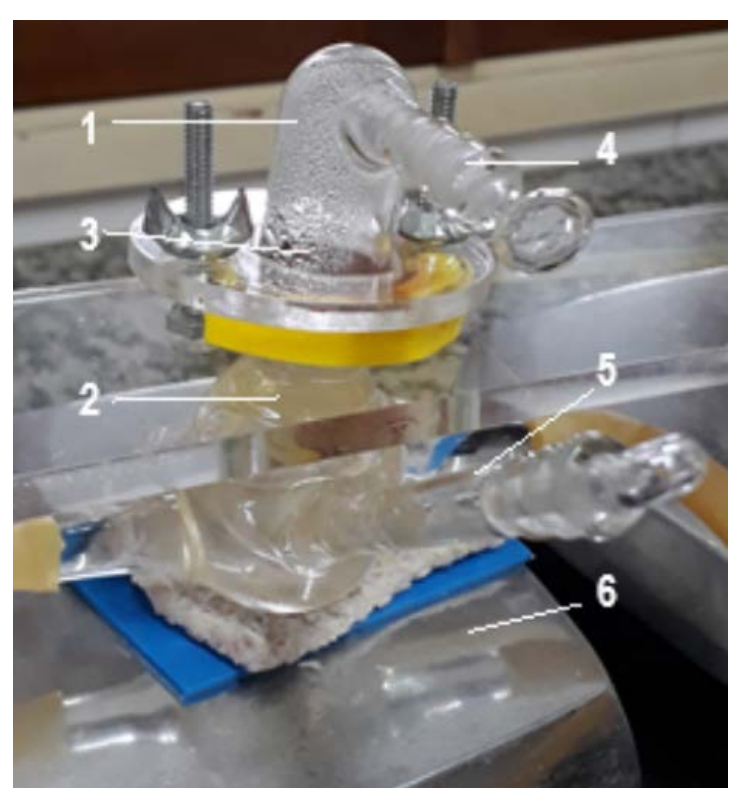

Figure 1. Photograph of Franz-type diffusion cells. 1: donor chamber; 2 : receptor chamber; 3: horse nasal mucosa; 4: Arm of donor compartment; 5: Arm of receptor compartment; 6: Magnetic stirrer station. Note: derived from research

\section{Measurement of butorphanol concentrations}

Butorphanol concentration was quantified using UV/Vis microplate spectrophotometer (Multiskan GO, Thermo Fisher Scientific) using a method previously validated (Velloso, et al. 2018). Butorphanol detection was carried out at $280 \mathrm{~nm}$ in UV-96-well microplate. Calibration curves were established by loading eight-fold eight concentrations of butorphanol tartrate in a range of $1-100 \mu \mathrm{g} \mathrm{ml}^{-1}$.

\section{Data analysis}

Plot of the cumulative amount of butorphanol $\left(\mu \mathrm{g} / \mathrm{cm}^{2}\right)$ against time $(\mathrm{h})$ were constructed per each Franz-type diffusion cell. The X-intercept of the extrapolated linear region gave the lag-time $(\mathrm{h})$. The slope of the linear portion of the graph provided maximum flux values at the steady state $\left(\mathrm{J}_{\mathrm{ss}}\right.$, $\left.\mu \mathrm{g} \mathrm{cm}^{-2} \mathrm{~h}^{-1}\right)$ and apparent permeability coefficients $\left(\mathrm{K}_{\mathrm{p}}, \mathrm{cm} \mathrm{h}^{-1}\right)$ were calculated according to the equation:

$$
\mathrm{K}_{\mathrm{p}}=\mathrm{J}_{\mathrm{ss}} / \mathrm{C}_{\mathrm{d}}
$$

Where $\mathrm{C}_{\mathrm{d}}$ is the drug concentration in the donor compartment; it is assumed that under sink condition the drug concentration in the receptor compartment is negligible compared to that in the donor compartment. Furthermore, $\mathrm{J}_{\mathrm{ss}}, \mathrm{K}_{\mathrm{p}}$ and lag-time of each cell, were averaged and their standard deviation calculated.

In all of cases, it was previously verified that the data met the assumption of independence, normality and homoscedasticity using Shapiro-Wilk test and Levene test.

Parameters obtained in each cell were statistically analyzed applying the software Statgraphics Centurion XVI.II. Analysis of variance (ANOVA) was used to compare values of $\mathrm{J}_{\mathrm{ss}}, \mathrm{K}_{\mathrm{p}}$ and lag-time for control, F1 and F2 from olfactory and respiratory nasal mucosa. Comparison between respiratory and olfactory parameters was performed by applying Student-t test. 


\section{Analysis and results}

Figure 2 shows the cumulative amount of butorphanol that permeated through horse olfactory and respiratory nasal mucosa for tested formulations. Mean $( \pm \mathrm{SD})$ for flux, apparent permeability coefficients and lag-time for respiratory and olfactory mucosa from control, F1 and F2 are shown in Table 2.
Assumptions of normality were accepted for $\mathrm{J}_{\mathrm{ss}}$ from olfactory region and lagtime from both regions. It was not true for $\mathrm{J}_{\mathrm{ss}}$ and $\mathrm{K}_{\mathrm{p}}$ from respiratory area, consequently the data was transformed with the following formula: $\sqrt{ }$ (observed value +1$)$. This transformation was accepted for respiratory $\mathrm{J}_{\mathrm{ss}}$, but not for $\mathrm{K}_{\mathrm{p}}$ from respiratory area. In this last case, it was necessary applied non-parametric

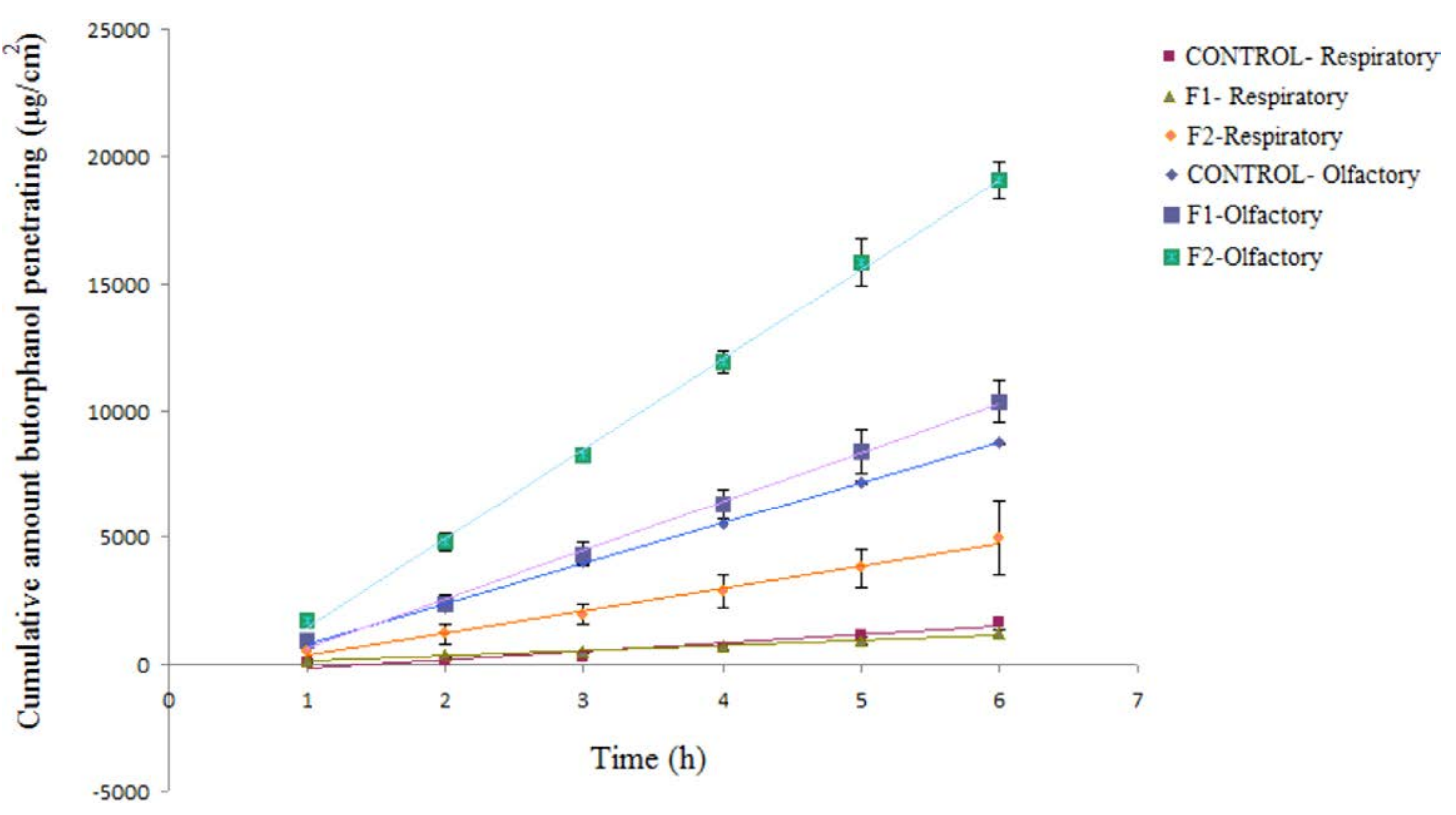

Figure 2. In vitro penetration of butorphanol through equine nasal mucosa using Franztype diffusion cells. There were used three formulations with butorphanol: F1 had CTAB, F2 contained Tween 80, and control formulation. Butorphanol tartrate was in a doses of $24.4 \mathrm{mg} / \mathrm{cm}^{2}$. Each point represents the mean $\pm S D$. Note: derived from research.

Table 2. Mean $\pm S D$ of butorphanol In vitro permeation parameters through horse nasal mucosa using Franz-type diffusion cells for the three tested formulations. $J_{\mathrm{ss}}=$ flux at the steady state. $K_{\mathrm{p}}=$ apparent permeability coefficient.

Note: derived from research.

\begin{tabular}{ccccc}
\hline \multirow{2}{*}{ Parameter } & $\begin{array}{c}\text { Anatomical } \\
\text { region }\end{array}$ & CONTROL & Formulation & F2 \\
\hline \multirow{2}{*}{$\mathrm{J}_{\mathrm{ss}}\left(\mu \mathrm{g} \mathrm{cm}^{-2} \mathrm{~h}^{-1}\right)$} & Olfactory & $1593.9 \pm 137.89$ & $1916.825 \pm 599.85$ & $3524.4 \pm 369.5$ \\
& Respiratory & $329.9 \pm 45.8$ & $205.45 \pm 97.33$ & $880.67 \pm 706.99$ \\
\multirow{2}{*}{$\mathrm{K}_{\mathrm{p}}\left(\mathrm{cm} \mathrm{h}^{-1}\right)$} & Olfactory & $0.065 \pm 0.006$ & $0.079 \pm 0.0246$ & $0.1445 \pm 0.015$ \\
& Respiratory & $0.014 \pm 0.002$ & $0.008 \pm 0.004$ & $0.036 \pm 0.029$ \\
\multirow{2}{*}{ lag-time $(\mathrm{h})$} & Olfactory & $-0.0117 \pm 0.7$ & $-0.581 \pm 0.4033$ & $-0.579 \pm 0.161$ \\
& Respiratory & $-1.47 \pm 0.3$ & $-0.0576 \pm 1.33$ & $-0.371 \pm 0.941$ \\
\hline
\end{tabular}


Kruskal-Wallis test. Assumptions of homoscedasticity were true in all cases except lag-time from olfactory area.

Comparison of $\mathrm{J}_{\mathrm{ss}}, \mathrm{K}_{\mathrm{p}}$ and lag-time from control, F1 and F2 for respiratory region do not show statistically significant differences $(\alpha=0.05)$. However, statistically significant differences on the values of $\mathrm{J}_{\mathrm{ss}}$ and $\mathrm{K}_{\mathrm{p}}$ from control, F1 and F2 in olfactory mucosa were observed $(\alpha=0.05)$.

Multi-range test was applied over these data which showed statistically significant difference $(\alpha=0.05)$ and it was proved difference between $\mathrm{J}_{\mathrm{ss}}$ from control formulation and F2 formulation. Moreover, it was proved statistically significant difference between $\mathrm{J}_{\mathrm{ss}}$ from F1 and F2 $(\alpha=0.05)$. Also, significant difference $(\alpha=0.05)$ on $\mathrm{K}_{\mathrm{p}}$ from olfactory area between control and F2 and between F1 and F2 were observed.

\section{Discussion}

Brain drug delivery is reduced by blood-brain-barrier, nevertheless, intranasal administration allows to avoid it, so the drug let into brain by direct and non-invasive path. This quality is profitable for the administration of drugs whose site of action is inside the central nervous system such as butorphanol (Velloso et al., 2019). Butorphanol is used in horses to treat superficial and visceral pain (Ferreira et al., 2019). Intranasal route allows a fast, non-pain and bloodless administration without causing greater stress to the animal with higher bioavailability because intranasal administration, also avoid first-pass metabolism which affects butorphanol directly.

Most of substances cross biological membranes through diffusion, a phenomena which is described by Fick Law (Haq et al., 2020) assuming that the velocity of transference per unit area (flux) of a membrane is a direct function of its thickness (Talevi \& Bellera, 2016, p 27), consequently is expected to butorphanol is more crossed through olfactory nasal mucosa than respiratory nasal mucosa, because the first is thinner than the second.

On the other hand, it is reported that maximum flux values at the steady state $\left(\mathrm{J}_{\mathrm{ss}}\right)$ from F2 showed statistically significant difference from F1. As control, F1 and F2 have similar chemistry composition except for F1 and F2 had been added CTAB and Tween 80 , respectively. It would be assumed that the observed differences reflect the presence of Tween 80 in the F2. This result is backed up by Gao et al., (2019) who reported an in vivo assay where rats were administrated intranasal 2,3,5,6-tetramethylpyrazine using different kind of formulation with different surfactant's concentration. It was demonstrated that the concentration of the drug inside the brain is significantly increased by Tween 80 (Gao et al., 2019).

Explicitly for butorphanol, it is anticipate that $\mathrm{J}_{\mathrm{ss}}$ value is statistically significant different with the added of surfactant inside the formulation. Butorphanol is a lipophilic drug whose $\log \mathrm{P}$ (octanol-water) is 3.68 (Grassin-Delyle et al., 2012; Jim et al., 2009). Generally, formulations for intranasal administration need the presence of one or more excipients with solubilizing activity to increase the velocity of dissolution and the possibility of absorption which together became an improvement of its bioavailability (Vetter et al., 2012). Developing formulation with surfactant whose aim is dissolve, emulsify, act as dispersant of suspensions or wetting agents can make changes in the biological membrane permeability which it is through or even, affecting their integrity (Tadros, 2014) that it would explain $\mathrm{J}_{\mathrm{ss}}$ obtained in this assay. 
Tween 80 is a hydrophilic non-ionic surfactant whose molecular formula is $\mathrm{C}_{58} \mathrm{H}_{124} \mathrm{O}_{26}$ widely used in medicinal and alimentary products (Prabhakar et al., 2013). Until now, the exact mechanism of action of Tween 80 remains unknown; however, it is accepted that is related to its chemical structure. Tween 80 is polyethylene chain with hydrophilic and hydrophobic characteristics, giving the ability of disorganize and dissolve intracellular lipids. Consequently it increases the fluency of cellular membranes from nasal mucosa. Furthermore, it was reported that Tween 80 is able to be placed between lipids and proteins in cellular membranes, disturbing and increasing the permeability of drugs; Tween 80 is linked to loss of tight junctions in tissues (Gao et al., 2019; Kaur \& Mehta, 2017). Results obtained in our assay suggested that Tween 80 would be a promissory excipient during the development of butorphanol formulations for intranasal administration in equines because it would increase its bioavailability. On the other hand, it should consider that the choice of surfactant it would not be because an improvement in drug penetration, but also its low toxicity in long-term (Gao et al., 2019; Som et al., 2012). Som and collaborators (Som et al., 2012) had reported that non-ionic surfactants critical micellar concentration (CMC) usually is less than CMC from surfactant with charge. This fact is supported by the characteristic that non-ionic surfactant are less irritant and better tolerated than anionic and cationic surfactants.

The lack of statistically significant differences between parameters $\mathrm{J}_{\mathrm{ss}}, \mathrm{K}_{\mathrm{p}}$ and lag-time between $\mathrm{F} 1$ and control might be reflecting that the presence of CTAB in the formulation did not improve and even reduce butorphanol penetration through equine mucosa.
CTAB is a cationic surfactant whose mechanism of action is linked to its ability of doing micelles with lipids from cellular membrane, which break the cellula (Cárdenas, 2016). As the efficacy of the most of penetration enhancers depends on their concentration (Haq et al., 2020), initially it is proposed that the used concentration of CTAB in this study was under the effective concentration for enhancing butorphanol penetration through equine nasal mucosa.

Chakraborty and collaborators (Cárdenas, 2016), studied the effect of carvediol dissolution, a hydrophilic drug used in heart failure treatment, with presence of different surfactant with widely range of concentration and $\mathrm{pH}$, showing that solubility was higher with the increase of CTAB concentration in all range of $\mathrm{pH}$ used, peaking at $\mathrm{pH}$ 3. Unfortunately in our study, the $\mathrm{pH}$ was fixed at 4.5 , therefore it could affected the penetration.

Our laboratory group had done previous in vivo studies where our control formulation was applied by intranasal administration (Ferreira et al. 2019) that showed our control formulation, had $\mathrm{T}^{1} 12$ abs of 0.426 $\pm 0.320 \mathrm{~h}$ with a bioavailability of $54.45 \pm$ $20.09 \%$. From the results obtained in this in vitro test, it is expected that in vivo administration of F2 formulation would lead to a significant increase in bioavailability. These results are very promising for continuing the development of formulations for intranasal administration in equines.

\section{Conclusions}

It is proposed that Tween 80 could be a promising excipient in the development of intranasal butorphanol formulations for using in equines because it would increase its passage through the nasal mucosa. Based 
on these data, it is expected to continue with the development on intranasal butorphanol formulations in equines.

\section{Acknowledgements}

Paper prepared within the framework of research projects PICT 2015-0926 (FONCYT/ANPCyT).

\section{Conflict of Interest}

The authors declare no competing interests.

\section{Author contribution statement}

The total contribution percentage for the conceptualization, preparation, and correction of this paper was as follows: M.I.V $60 \%$., M.F.L $30 \%$ and A.A. $10 \%$.

\section{Data availability statement}

The data supporting the results of this study will be made available by the corresponding author, [MIV], upon reasonable request.

\section{References}

Cárdenas, L. N. (2016). Diseño de soluciones químicas para la extracción de ácido desoxirribonucleico en productos biotecnológicos. UGCiencia, 22(1), 37-44. https://doi. org/10.18634/ugcj.22v.1i.553

Dale, O., Hjortkjaer, R., \& Kharasch, E. D. (2002). Nasal administration of opioids for pain management in adults. Acta anaesthesiologica scandinavica, 46(7), 759-770. https://doi. org/10.1034/j.1399-6576.2002.460702.x

Ferreira, V., Teme Centurion, O., \& Landoni, M.F. (2015). Evaluación de la vía intranasal para la administración de opioides en equinos. Invet, $17,63-64$.
Ferreira, V., Velloso, M. I., \& Landoni, M. F. (2019) Bioavailability of butorphanol after intranasal administration to horses. Bulgarian Journal of Veterinary Medicine. http://tru.uni-sz. bg/bjvm/bjvm-2019-0051\%20OnFirst.pdf

Franz, T. (1978). The finite dose technique as a valid in vitro model for the study of percutaneous absorption. Current Problems in Dermatology, 7, 58-68. https://doi.org/10.1159/000401276

Gao, M., Mei, D., Huo, Y., \& Mao, S. (2019). Effect of polysorbate 80 on the intranasal absorption and brain distribution of tetramethylpyrazine phosphate in rats. Drug delivery and translational research, 9(1), 311-318. https://doi. org/10.1007/s13346-018-0580-y

Grassin-Delyle, S., Buenestado, A., Naline, E., Faisy, C., Blouquit-Laye, S., Couderc, L. J., Guen, M. L., Fischler, M. \& Devillier, P. (2012). Intranasal drug delivery: an efficient and non-invasive route for systemic administration: focus on opioids. Pharmacology \& therapeutics, 134(3), 366-379. https://doi. org/10.1016/j.pharmthera.2012.03.003

Haq, A., M., Chandler, M., \& Michniak-Kohn, B. (2020). Solubility-physicochemical-thermodynamic theory of penetration enhancer mechanism of action. International Journal of Pharmaceutics, 575, 118920. https://doi. org/10.1016/j.ijpharm.2019.118920

Jim, E., Riviere, J. E., \& Papich, M. G. (2009). Veterinary Pharmacology and Therapeutics. New York, United States.

Kaur, G., \& Mehta, S. K. (2017). Developments of Polysorbate (Tween) based microemulsions: Preclinical drug delivery, toxicity and antimicrobial applications. International journal of pharmaceutics, 529(1-2), 134-160. https:// doi.org/10.1016/j.ijpharm.2017.06.059

Matthews, N. S., \& Carroll, G. L. (2007). Review of equine analgesics and pain management. Proceedings of the Annual Convention of the American Association of Equine Practitioners (pp. 240-244). Orlando, Florida.

Prabhakar, K., Afzal, S. M., Surender, G., \& Kishan, V. (2013). Tween 80 containing lipid nanoemulsions for delivery of indinavir to brain. Acta Pharmaceutica Sinica B, 3(5), 345-353. https://doi.org/10.1016/j.apsb.2013.08.001

Som, I., Bhatia, K., \& Yasir, M. (2012). Status of surfactants as penetration enhancers in transdermal drug delivery. Journal of 
pharmacy \& bioallied sciences, 4(1). https:// doi.org/10.4103/0975-7406.92724

Tadros, T. (2014). Colloid and interface aspects of pharmaceutical science. H. Ohshima \& K. Makino (Eds.), Colloid and Interface Science in Pharmaceutical Research and Development. Oxford, UK, Elsevier, 29-54. https://doi. org/10.1016/B978-0-444-62614-1.00002-8

Talevi, A. \& Bellera, C. L. (2016). Absorción de fármacos. A. Talevi, P. Quiroga, \& M. E. Ruiz (Coords.), Procesos biofarmacéuticos (pp. 25-38). Editorial de la Universidad de La Plata. https://doi.org/10.35537/10915/51907

Thorat, S. (2016). Formulation and Product Development of Nasal Spray: An Overview. Scholars Journal of Applied Medical Sciences, 4(8D), 2976-2985.
Velloso, M. I., Ferreira, V., Vita, M., \& Landoni, M. F. (2019). Vía intranasal: Una alternativa para la administración de fármacos de acción central en equinos. Analecta Veterinaria, 39(1), 033. https://doi.org/10.24215/15142590e033

Velloso, M. I., Andreeta, A., \& Landoni, M. F. (2018). Puesta a punto un método espectrofotométrico UV/Vis en microplaca para la cuantificación de butorfanol en exposición oral. En VIII Jornadas de Jóvenes Investigadores, 2018. Facultad de Ciencias Veterinarias, Universidad Nacional de Buenos Aires.

Vetter, A., Augustijns, P., \& Bernkop-Schnürch, A. (2012). Solubilizing agents in nasal formulations and their effect on ciliary beat frequency. Toxicology in Vitro, 26(1), 150-156. https://doi.org/10.1016/j.tiv.2011.10.011

\section{(c) $\underset{\mathrm{BY}}{\mathrm{NC}} \Theta_{\mathrm{ND}}$}

Effect of two surfactants on in vitro permeation of butorphanol through horse nasal mucosa (María Inés Velloso • Héctor Alfredo Andreetta • María Fabiana Landoni) Uniciencia is protected by Attribution-NonCommercial-NoDerivs 3.0 Unported (CC BY-NC-ND 3.0) 